ISSN: $1412-4734$

E-ISSN: 2407-8646

Volume 18, Number 1, 2018

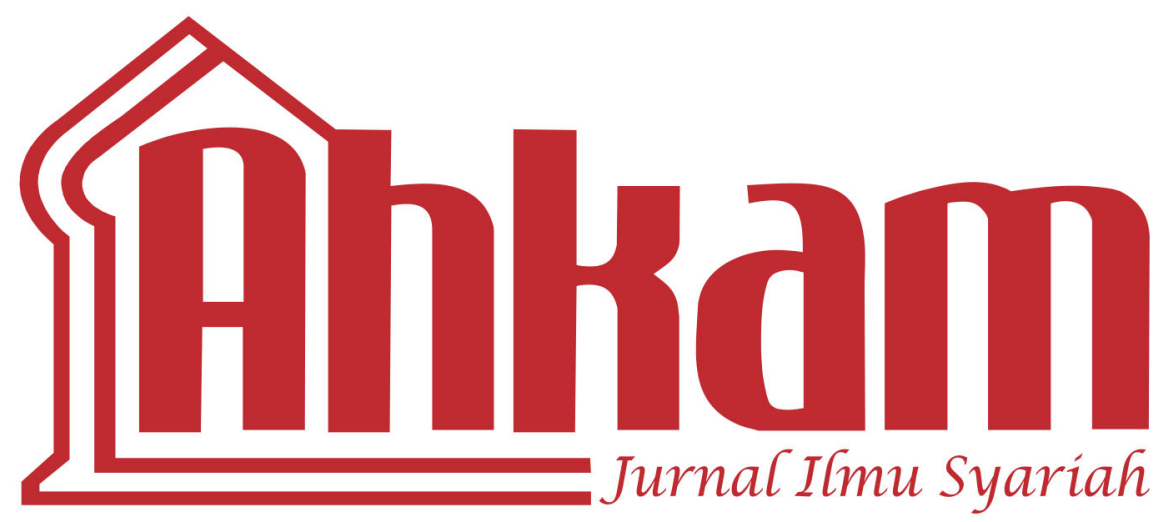

* Herdi Sahrasad \& Al Chaidar

Indonesian Terrorist, ISIS, and Globalization of Terror: A Perspective

* Hotnidah Nasution

Implementation of the Principle of Ultra Petitum Partium in Deciding Children Livelihood in Divorce Lawsuit in Religious Courts

* Havis Aravik, Choiriyah \& Saprida

Critical Study on the Legal Thinking of Muhammad Shahrur

* Nita Triana

Urgency of Arbitration Clause in Determining the Resolution of Sharia Economic Disputes

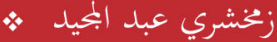

أهمية قوانين المصارف الشرعية في إنلدونيسيا (نظرية التقسير الموضوعى)

* Arrisman

Islamic Law And Business Ethics: Case Study of Forest Fires for Clearing the Lands 


\section{Mhliam}

Volume 18, Number 1, 2018

EDITOR-IN-CHIEF

Khamami Zada

EDITORS

Fathudin

Maman R Hakim

Windy Triana

Nur Hidayah

Ahmad Bahtiar

INTERNATIONAL EDITORIAL BOARD

Tim Lindsey (University of Melbourne Australia)

Nadirsyah Hosen (Monash University Australia)

Ahmad Hidayat Buang (Universiti Malaya Malaysia)

Raihanah Azahari (University Malay Malaysia)

Mark Elwen Cammack (Southwestern University)

Razeen Sappideen (University of Western Sydney)

Carolyn Sappideen (University of Western Sydney)

Nik Ahmad Kamal bin Nik Mahmod (International Islamic Universiti Malaysia)

Ahmad Tholabi Kharlie (UIN Syarif Hidayatullah Jakarta)

Muhammad Atho Mudzhar (UIN Syarif Hidayatullah Jakarta)

Masykuri Abdillah (UIN Syarif Hidayatullah Jakarta)

Muhammad Amin Suma (UIN Syarif Hidayatullah Jakarta)

M. Arsykal Salim GP (UIN Syarif Hidayatullah Jakarta)

Asep Saepudin Jahar (UIN Syarif Hidayatullah Jakarta)

ASSISTANT TO THE EDITORS

Kamal F. Musa

Erwin Hikmatiar

ENGLISH LANGUAGE ADVISOR

Bradley Holland

Umi Kulsum

ARABIC LANGUAGE ADVISOR

Amany Burhanudin Lubis

AHKAM has been accredited based on the determination of Director General of Research Reinforcement and Development, Research, and Technology Ministry of Higher Education of Republic of Indonesia, No. 36/a/E/KPT/2016 (valid until 2021). 
AHKAM Jurnal Ilmu Syariah (ISSN: 1412-4734) is a periodical scientific journal published by Faculty of Sharia and Law of Syarif Hidayatullah State Islamic University Jakarta in collaboration with Indonesian Scientist and Sharia Scholar Association (HISSI). This journal specifically examines the science of sharia and obtains to present various results of current and eminence scientific research. The administrators receive articles as contributions Sharia and Islamic law disciplines from scientists, scholars, professionals, and researchers to be published and disseminated.

\section{EDITORIAL OFFICE:}

Fakultas Syariah dan Hukum UIN Syarif Hidayatullah Jakarta

Jl. Ir. H. Juanda 95 Ciputat, Jakarta 15412

Telp. (+62-21) 74711537, Faks. (+62-21) 7491821

Website: http://journal.uinjkt.ac.id/index.php/ahkam/index

E-mail: Jurnal.ahkam@uinjkt.ac.id 


\section{Table of Contents}

1 Herdi Sahrasad \& Al Chaidar

Indonesian Terrorist, ISIS, and Globalization of Terror:

A Perspective

23 Hotnidah Nasution

Implementation of the Principle of Ultra Petitum Partium in Deciding Children Livelihood in Divorce Lawsuit in Religious Courts

43 Havis Aravik, Choiriyah \& Saprida

Critical Study on The Legal Thinking of Muhammad Shahrur

65 Nita Triana

Urgency of Arbitration Clause in Determining The Resolution of Sharia Economic Disputes

89

زخشري عبد المجيد

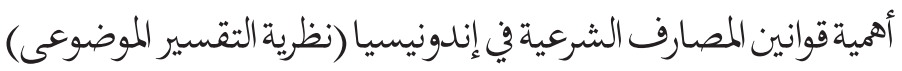


109 Arrisman

Islamic Law and Business Ethics: Case Study of Forest Fires for Clearing The Lands

125 Abdulmajeed Hassan-Bello

Riba and Islamic Banking, Examining the Practices of Jaiz Bank PLC, Nigeria

155 ISNaWATI Rais

Marriage Dispensation due to Extramarital Pregnancy: The Study on the Decision by the Religious Court of South Jakarta (2010-2011)

177 HaMZAH

Zakah Empowerment Optimization Through Baitul Ikhtiar Cooperation as an Effort in Poverty Alleviation in Bogor Regency

201 Abdul Muta'Ali

Israel and Palestine Conflict from Linguistics and Figh

Siyasah Perspective

219 Susiknan Azhari

Tracing the Concept of Fajr in the Islam Mosaic and Modern Science

233 Ahmad Sholihin Siregar

The Construction of Āyātul Aḥkām (Constructing the Selection Bases of Āyātul Aḅkàm) 


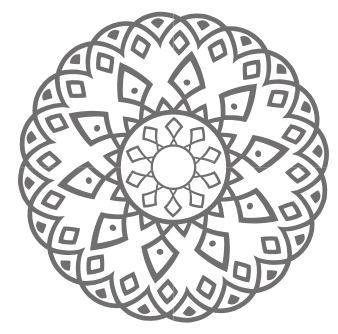

\title{
Israel and Palestine Conflict from Linguistics and FiQh SiYASAH Perspective
}

\author{
Abdul Muta'ali
}

\begin{abstract}
Abstrak: Penelitian ini didasarkan atas desain bahasa daalam teks-teks keagamaan dengan solusi diplomatis terhadap konflik Israel-Palestina menurut perspektif Fiqh Siyasah. Sejak konflik anatara dua negara tersebut pada tahun 1974 hingga saat ini, dalam konteks geo-politik bahwa solusi perdamaain di dua kawasan ini adalah menjadikan persepsi internasional terhadap konflik ini sebagai mediator. Alsannya adalah adanya kesamaan dengan desain bahasa dalam teks-teks Qur'an yang selalu menggunakan bentuk plural. Menariknya, jumlah Yahudi di dunia berjumlah 15 juta, dibandingkan dengan 250 juta jiwa penduduk Indonesia, namun Qur'an tidak pernah menggunakan kata ganti untuk yahudi sebagai grup minoritas atau bahkan selalu menyebutnya sebagai mayoritas. Dalam fiqh siyasah, jika hal ini terjadi, maka terdapat beberapa alternative; manfaat prioritas dan Sad Dzari ah. Sumber data yang digunakan adalah Al-Qur'an dan hadits Nabi. Metode yang digunakan dalam penelitian ini adalah menganalisa data bibliografi dengan pednekatan analisa konten (isi). Kajian ini berkesimpulan bahwa ditemukan perbedaan dalam teks dan konteks dalam upaya-upaya resolusi konflik-konflik Israel-Palestina dan dalam solusi perdamaian kedua negara.
\end{abstract}

Kata kunci: desain linguistik, konflik Israel-Palestina, solusi dua negara, Fikih Siyasah 
Abstract: This research is based on the linguistic design of religious texts with diplomatic solutions to the Israeli-Palestinian conflict based on the perspective of Figh Siyasah. Since the conflict of these two nations in 1947 to the present day, in the geopolitical context that the solution of the presence of peace in these two regions is to equate the international perception to this conflict as a mediator. The reason is that there is an alignment with linguistic design on the text of the Qur'anic verse which always' uses a plural form. Interestingly, the number of Jews in the world is 15 million, compared with Indonesia 250 million people, but the Qur'an never uses pronouns for Jews as a minority group or even always mentioned the majority. In the Siyasah fiqh, if this happens may take several alternatives; priority and Sad Dzari'ah benefit. Sources of data used are the Qur'an and the hadith of the prophet. The method used in this research is to analyze bibliography data with content analysis approach . The study concludes that there are differences in text and context in the efforts to resolve the Israeli-Palestinian conflict and the twostate peace solution.

Keywords: linguistic design, Israeli-Palestinian conflict, two-state solution, Fiqh Siyasah

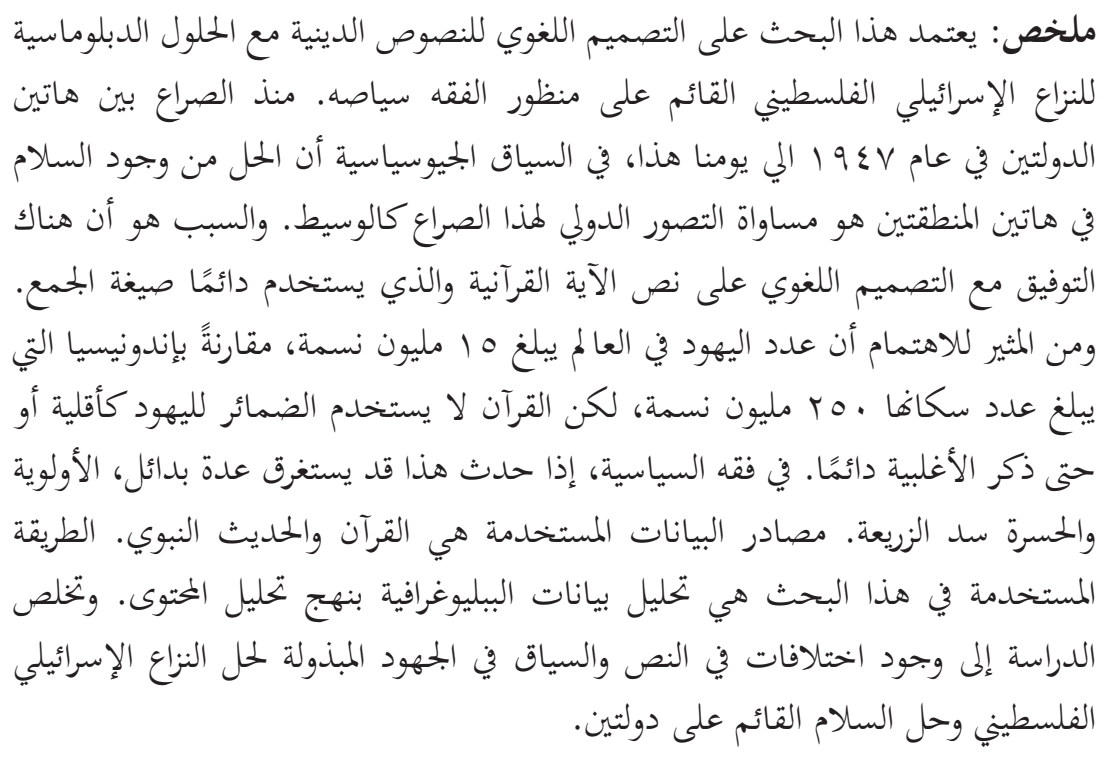




\section{Introduction}

This research is grounded in the harmony of linguistic design information in several religious texts with diplomatic solution for Israel-Palestine conflict. Since the conflict emerged in 1947, base on international geopolitical context that the solution for peace in the two states is to start creating the same international perception on the conflict. The linguistic design in several Qur'anic verses which uses plural form at all times for the mediator side. Jews had established a station in 14 May 1948 with the majority of UN members. Thus, the peaceful diplomatic effort must be done extensively with the support of majority. Israel-Palestine conflict seems like eternal unsolvable battle. Since 2008, Israel cruelty by their military aggression has been inhumane and a massacre to Palestinians, even children, women and the elder. It is worsened with the establishment of illegal Israeli settlement and the Muslim ban to enter and pray in Al-Aqsa Mosque. If it is still happening, it is not impossible that the third intifada will emerge.

Geopolitically, Gaza is the last defense for Hamas who are not open to any negotiation to divide Palestine territory unless it is in the accordance with Palestine territory in the 1947 agreement. Even so, Ramallah under Fatah control still tolerates the division for the two states. From geostability point of view, territory of Gaza which is controlled by Hamas is a threat to Zionist Israel. Hamas demands Palestine to be a sovereign state and to have the right of state defence. Israel repeatedly attack Gaza. However, it is the only zone that Palestine occupy and control because Ramallah and Jerussalem in which Al-Aqsa Mosque is located is decrease by the Israel occupation and slowly lose from the Palestinians.

However, the blody conflict of Israel-Palestine must stop. In the modern world, it is ironic to have a country, specifically Palestine, that is not yet sovereign. A comprehensive diplomacy and the unity of international citizen are two of significant ways to end the conflict. Not even to be a strong state as it was said by Ibnu Khaldun or Machiavelli, yet to be an independent state for Palestine seems like an impossible mission (Muta ali, 2013: 75-80). Probably, the independence of Palestine is only an endless misywar 
(road) (Muta ali, 2009: 35). The hypotheses of the research is that there is an accordance between the texts and contexts in the conflict of Israel-Palestine and a peaceful solution for the two states (AlAmmaari, 2001:80 and Umar,1998).

\section{A New Concept of Israel-Palestine Conflict Mediation}

Israel-Palestine conflict is a huge unfinished 'homework' for international citizen. Therefore, the academic efforts to undergo studies of diplomacy for the conflict is not only anticipated by Indonesia government but also international institutions such as the United Nations, the Organisation of the Islamic Conference, and other peacemaker organisations. Also international indexed publications are waited for findings and new hypotheses to pursue justice and peace in Jerussalem. This paper offers a new approach which was never used before. It is an approach of linguistic information or linguistics. The more common approaches are political and military. The world has seen and understood of what the two approaches have accomplished. With a humble heart, this new approach is hopefully more effective, not only as an academic paper but also making peace for the land of the Prophets.

In the knowledge of the author, studies and researches about the conflict so far, none of them discussed linguistics as the ground problem and solution. Since the conflict is not new, it is known that numbers of studies and researches have been done about the topic. There is variety in terms of its forms; from journals, conferences, and declaration material and resolution. Yet none of them finds 'linguistic design' as an approach for this conflict studies.

As we all know, the conflict started in 1947 and until now Palestine is not independent yet. Our own constitution says that "the occupation in the world must be banished". Moreover, in one of Bung Karno's speech, he said, "as long as Palestine is not independent, then that long Indonesia is struggling together with the Palestinians."

\section{Kaleidoscope of Israel-Palestine Conflict}

Abdul Mutaali on Media Indonesia newspaper 27 July 2017 in an article entitled Kapan Berhentinya Konflik Israel-Palestina? ("When 
will the Conflict of Israel-Palestine End?") said that Israel do not only massacre and threat physically, but also kill the faith of the Palestinians. They ban the adzan (prayer calling) and the prayer in the first kibla of Muslim. Moreover, Israel-Palestine conflict is the longest tragedy of humanity after the World War II. Even Timor Leste has been apart from Indonesian and gained its independence in 2000. Agreements, summits, or even the Palestine flag raising in the United Nations headquarters have yet been a success to lessen the crime of Israel over Palestine. The long-awaited independence has yet to arrive. The irony of Palestine is the irony of human rights and all the fighters (Muta'ali, 2017).

Before the occupation and the human rights violation of the people of Palestine done by Israel in 14 July 2017 is not the only one or the first ever. The aggression of Tel Aviv soldiers has been done every day since 1967. If we count the days since British was appointed to protect the holy city of Jerussalem, it has started since 1940-ish. It means that the age of oppression over and the struggle of Palestine for their sovereignty equal with the age of Indonesias independence. Yet, until today Palestine takes a little attention of the United Nations. The event of 15 July 2017 was similar to the attack in Hebron Mosque in 2004. 24 casualties were killed in the shooting during Friday prayer putting international and Islamic world were in rage. This case was taken to the UN Security Cuncil. All of permanent members of the UN Security Council agreed to give sanction for the brutality of Israel soldiers. Unfortunately, the United State vetoed over the sanction for Israel in the reasons of the shooting suspects were mentally ill Israeli soldiers (Muta'ali, 2017).

The problems between Israel and Palestine was apparently less complicated than the Arab Spring and Syrian conflict. The main reason is that the people and the alligator behind the conflict is widely known. It is one form of the global injustice which violates the humanity. Furthermore, it is the realest form of terrorism. As long as this injustice is still shown, the foundation of humanities will be shaken. De-radicalisation and contra-radicalism which are loudly outspoken in various forum are being confronted by the Israel hegemony and then weakened. That is why from all the variable of terrorism, Israel is always counted in each of them. We are too 
busy to take care the downstream of the problem but we forget the upstream. All that Palestine need and hope for is justice and the right for independence (Muta'ali, 2017).

The existence of Israel as a state is a manifestation of racist ideology in this worldly order. It emergence would banish the Palestinian entities. Even more, their own land of territory is diminished as the time goes. The shooting in 14 July 2017 is a proof of crime against humanity by Israel to Palestine. They do not only kill their physics but also kill their 'God'. They shut Al-Aqsa Mosque, ban the prayer calling, kick the prayer, and threat them with their lethal weapons. World should not be silent to respond this. There are many countries namely Egypt, Sweden, and France urged the UN to immediately respond this crime. Indonesia in the OIC Summit on April 2015 proposed a concept of Two-State Solution which was previously proposed by the European Union. This concept allows Israel and Palestine to have their own independent state. However, Palestine through Hamas governance have their own definition of independent. They will take the peace agreement only if they have the land that was taken and occupied by Israel since 1967 or in other words, they want their whole Palestine territory back. Interestingly, in one of Barack Obama's speech, he said that it is what Israel is supposed to do from Palestine's demand: to return the land to Palestine. Nonetheless, the lobbying went cold and resulted on nothing until Hamas lowered their bargain to the land of Palestine that was taken after the Second Intifada in the late of 1970-ish (Muta'ali, 2017).

There are numbers of signed agreements, some are not only between Israel and Palestine but also included other countries such as Egypt, the United States, Qatar and Jordan. Yet the tragedy of humanity has shown any sign to end or even to be an independent state for Palestine. There was Camp David Agreement facilitated by the President of the United States Jimmy Carter in 17 September 1978 and signed in the White House. This agreement took 12 days between Anwar Saddat, the President of Egypt and the Prime Minister of Israel, Menachim Begin. The agreement took after the name of the resting place owned by the President of the United States, Camp David in Frederick County, Maryland. It was a more benefit for Egypt rather 
than Palestine itself. The subjects of Camp David Agreement are: (1) the acknowledgement of the Arabs of Israel; (2) the withdrawal of Israel soldiers in the settlement territory that was occupied during the war; and (3) the agreement that other countries would not threat Israel security and will not divide Jerussalem to any other parties (Editorial Team ASPAC for Palestine, 2014: 412).

In 13 September 1993, there was Oslo Peace Accord signed by Yasser Arafat and Yitzak Rabin in Washington which then became the negotiable foundation held in Oslo, Norway. The major points in the accord is organizing Palestine Authority which consisted of West Bank and Gaza Strip. In return, Palestine should promote tolerance for Israel and acknowledge the entity of Israel as a nation. Then, one side ceasefire happened in 17 January 2009. In fact, a moment earlier, Israel had done military aggression by bombing Gaza for 22 days in a row (27 December 2008 - 18 January 2009). Two days later, Hamas announce a ceasefire. There was also an announcement of the Israel - Palestine ceasefire through press release by The Minister of Foreign Affairs of the United States Hillary Clinton and The Minister of Foreign Affairs of Egypt on November 2012 (Editorial Team ASPAC for Palestine, 2014: 412).

Furthermore, there was The Wye River Memorandum as an agreement between Israel and Palestine which was mediated by the United States in Aspen Institute Wye River Conference Center. It prominent theme was the implementation of interim agreement of West Bank and Gaza Strip which was signed in 23 October 1998. Then, Camp David Summit in 11-25 July 2000, the President of the United States became the host of the meeting between Yasser Arafat and Prime Minister Ehud Barak. Lastly, Road Map for Peace was an effort to create the state of Palestine in 2005. This time, Jordan was the host with the attendance of President George W. Bush, Ariel Sharon, and Mahmud Abbas. As likely, all of these agreements were a total failure.

What is intriguing from all the agreements is that the United States has always been the facilitator and the mediator and none of them succeeded. It is personally a huge question mark. Let us see how the textual signs between Israel and the United States and the solution 
for the following peace accords in the future will bring a success and implementable. This was once noted in Peta Baru Politik Timur Tengah ("The New Map of Politics of the Middle East), in Dari Indonesia Memandang Dunia ("Seeing the World from Indonesia") (Muta'ali, 2017:78).

Why al-Aqsa Mosque is really important for Israel? The core of the problem between Israel Palestine is the following explanation. It is the claim of possession and single authorisation of the first qibla. The UN recorded Jerussalem I which Al-Aqsa Mosque is located and the destination of the Prophet Muhammad in Isra was once occupied by the British as international representative. What is the message behind the attack of Israel to the worshipper and the pilgrim to the Holy Mosque? Presumably, Israel has the confidence and the power to do it. The Islamic world is in its weakest condition looking at the Arab Spring, Syrian conflict and the clash of Riyadh and Doha. Every one of the Arabs is drown in their own problems. If it is examined from conspiracy theory, there is contribution of Tel Aviv to all the conflicts happening in the Middle East. Then, Israel wants to convince the international world there is no reason to object their existence as a state. The brutality done by Israel is nothing compared to the cruelty and the crime of Islamic State (IS). Nevertheless, it is merely an argument and such an illogical concept. If really IS fight for Islam, why are they not present to fight for Palestine against Israel? Thirdly, Israel demands President Donald Trump's promise to make Jerussalem the capital of Israel. Trump once said in his coronation, but he created global tensions and he cancelled his idea. Israel using their classical moves to help Trump realize what was once he promised to them (Muta'ali, 2017).

In the interview with Republika 13 July 2014 published in Islam Digest edition I proclaimed that Gaza as an ancient city of a world civilization, particularly for the history of the divine religions (Jews, Christian and Islam). Gaza and Jordan territory was once a part of Syam area. In this area of Syam, the holy books of the divine religions explain the important role from the earlies prophets until the period of the Prophet Muhammad. The group of ablul kitab, Jewish and Christian have their own nubuat (prophecy) to this land of Syam. To 
begin with the promised land for the Jewish, the land where Jesus grew up for the Christian, and the land that the Prophet Muhammad had prepared to be the last for Muslim defence in the end of the world. From geographical perspective, Gaza is entry gate in the border of Palestine to Egypt. Moreover, it is more than a half of fertile area in Palestine which is now occupied by Israel. Geopolitically, Gaza is one of the last defence for the fighting group of Hamas which do not want to negotiate in the territory division of Palestine unless it is according to Palestine territory in 1946 agreement. Even though Ramallah which is authorized by Fatah is still open for negotiation of the two-state solution. From the perspective of geostability, Gaza which is controlled by Hamas is a threat to Zionist Israel.

Hamas insist that not only they want an independent right for Palestine but also the right for state defence. In result, Gaza is the defence. Losing Gaza to Israel means that a loss to Palestine as a whole country, because only Hamas that completely fight against Zionist Israel. Gaza as a part of Syam once taught theology to fight against tyranny. From its terminology, Gaza means 'the city of war'. Here in Gaza was a part of Syam where Abraham began his journey to go against King Namrud; the birthplace of Imam Shafi ' $i$ and the land where Jesus spent his childhood. It was also the area where the Prophet Muhammad passed by to do his first business trip across the Arab. It was once recorded in hadith that before the Prophet Muhhamad started mi raj to seven skies in Baitul Maqdis, he faced to this area and said that it would be the last defence of Muslim in the end of the world. In short, Gaza is the last defence for Palestinians. It is the only zone that the Palestinians really own. In fact, Ramallah and Jerussalem in which al-Aqsa Mosque is located is gradually occupied by Israel and will immediately slip from Palestinians' hands. What needs to be the attention is why even so many time Israel attack Gaza, but they never really accomplished anything nor occupy this land (Muta'ali, 2014).

In my opinion, it is because the inability of Israel to face the bravery of the Palestinian fighters in Gaza. They might have tanks, drones and other advance war equipment which in human logic will not be defeated by the stone throwing from the Palestinians. Israel 
fears for the spirit of jihad from the Palestinians fighters head to head. Looking back from 2008. Israel repeatedly attack Palestine during Ramadan. They think during Ramadan Muslim would be in their weakest condition. In fact, for the fighters in Gaza, nothing could stop them to take up arms against the Israeli soldiers and their war machine (Muta`ali, 2014).

Intifada is a movement of Palestinians struggle. In intifada, every element of Palestinian fighters worked together and teamed up to fight against Israel. In the first Intifada between 1987 to 1993, it ended with an agreement of the establishment of Palestine Liberation Organization. The second Intifada occurred in 2000 as a bloody struggle ended with a ceasefire. The attack of Israel could trigger the third Intifada. This cruel attack should be a momentum for Islamic and international world to urge the UN giving sanction and stopping Israel's brutality. This momentum should also make a force of Islamic world to undo all the support for the Zionist state. Although personally, I hope the least thing can be done is to stop immediately the brutal attack of Israel by a prompt international demand, including Indonesia (Muta`ali, 2014).

\section{Linguistic Exploration}

The word 'Israel' appears 43 times in the Qur'an. Intriguingly the word 'Israel in the Qur'an always appears together with word 'bani' as 'Bani Israel. It is only once when the word 'Israel appears independently without 'bani' in chapter Ali Imran verse 93 (Baqi, 1364 $\mathrm{H}: 33)$. In the same verse, the word 'Israel appears two times. The first time appear conjointly with the word 'bani' as 'Bani Israel' and another time comes without 'bani' as only 'Israel'. The verse says, "kullu aththasaami kaanna hillan li banii Israaiiila illaa maa harrama Israaiiilu salaa nafsibii min qabli an tunazzala at-tauraatu. Qul fastuu bi attauraati fatluuhad in kuntum shaadiqiiin,' which means "All food was lawful to the Children of Israel except what Israel had made unlawful to himself before the Torah was revealed. Say, [O Muhammad], «So bring the Torah and recite it, if you should be truthful." (Ministry of Religious Affair of Republic of Indonesia, 2018).

While word 'Yahudi (Jews)' appears nine times in the Qur'an and 
in fact, all of the meaning has negative connotation. Nine words of 'Yahudi (Jews)' are:

\begin{tabular}{|cllc|}
\hline No. & \multicolumn{1}{c}{ Text } & Chapter & Verse \\
\hline 1 & $\begin{array}{l}\text { Wa qaalat al-yahuudu laysat al-nashaara } \\
\text { alaa syai'i }\end{array}$ & Al-Baqarah & 113 \\
\hline 2 & $\begin{array}{l}\text { Wa qaalat al-nashaara laysat alyahuudu } \\
\text { 'alaa sya'i wahum yatluunal kitaaba }\end{array}$ & Al-Baqarah & 113 \\
\hline 3 & $\begin{array}{l}\text { Wa lan tardhaa 'anka alyahuudu wa laa } \\
\text { alnashaara hattaa tattabi'a millatahum }\end{array}$ & Al-Baqarah & 120 \\
\hline 4 & $\begin{array}{l}\text { Wa qaalat alyahuudu wa alnashaara } \\
\text { nahnu abnaa'u Allah wa ahibbaa'uh }\end{array}$ & Al-Maidah & 18 \\
\hline 5 & $\begin{array}{l}\text { Yaa Ayyuhalladzina aamanuu laa } \\
\text { tattakhidzuu alyahuuda wa alnashaara } \\
\text { awliyaa’a }\end{array}$ & Al-Maidah & 51 \\
\hline 6 & $\begin{array}{l}\text { Wa qaalat alyahuudu yadullah } \\
\text { maghluulah ghullat aydiihim wa lu'inuu } \\
\text { bimaa qaaluu }\end{array}$ & Al-Maidah & 64 \\
\hline 7 & $\begin{array}{l}\text { La tajidanna asyaddannaasi adaawatan } \\
\text { lilladziina aamanuu alyahuuda walladzina } \\
\text { asyrakuu }\end{array}$ & Al-Maidah & 82 \\
\hline 8 & $\begin{array}{l}\text { Wa qaalat alyahuudu uzairu ibnullah. Wa } \\
\text { qaalat alnashaara almasiihu ibnullah }\end{array}$ & At-Taubah \\
\hline 9 & $\begin{array}{l}\text { Maa kaana Ibraahimu yahuudiyyan wa laa } \\
\text { nashraaniyyan walaaakin kaan haniifan } \\
\text { musliman }\end{array}$ & Ali Imran & 67 \\
\hline
\end{tabular}

From the explanation of those two words, 'Israel and 'Yahudi (Jews)', some major points could be drawn. Started with the word 'Israel, the substances are: First, The word 'Israel' in the Qur' an appear 43 times and neither one of them appears alone. It always comes together with the word 'bani' as 'Bani Israel. An exceptional case is in 
chapter Ali Imran verse 93. It is seen that the word 'Israel' cannot stand alone without back up from the word 'bani' as it happens in the real life of Israel today. They would not exist without the support of United States, United Kingdom and the United Nations. As long as the word 'bani' conjoint the word 'Israel' as 'Bani Israel, Israel have negative textual meaning. It means that as long as Israel is supported by Bani (US, UK and the UN), the human rights violation will still exist. In short, the word 'Bani' brings negativity to Israel. Second, on the other hand, the word 'Israel' when it stands alone only as 'Israel and not 'bani Israel, it becomes a positive word. In pragmatics, it means without the help of US, UK and the UN, Israel would think twice to do genocide to Palestine and possibly become a peaceful part of the international world. If 'Israel' comes solo without 'bani', the given meaning will be Jacob and his kind characteristics. An analogical argument appears as the following: a child who is confidently committed a crime is usually the one with elder people who cover him unless he is out of his mind, as it is in the case of Israel. Thus, how the international world convinces US and UK through the UN to stop this is our homework. It is presumably an astonishing textual sign finding.

There is another way if the effort to convince US and UK through the UN fails. It is to boycott the products of Israel. It is seen from the text " $k$ ullu ath-tha'aami kaanna hillan li banii Israa'iila illaa maa harrama Israa'iilu 'alaa nafsihii min qabli an tunazzala at-tauraatu" ("All food was lawful to the Children of Israel except what Israel had made unlawful to himself before the Torah was revealed") (Q. 3:93). It is an effective textual sign. Yet the international world should be sure that the crime of Israel should not be connected to religious issues. What happens in Palestine is a crime against humankind. I personally see 'human diction' is what more acceptable rather than primordialism in the light of there are different religions in the world but the humanity of international world is the basic natural value and acquirable. While the analysis for the word 'Yahudi (Jews)' is explained in the following points:

1. The word 'Yahudi appear nine times in the Qur'an: (2:113); (2:113); (2: 120); (3:67); (5: 18); (5: 51); (5: 64); (5:82): (9:30). All of them has negative meaning. It means Jews is a belief and one of the divine religions. Saying Jews is a bad religion would add more problems and conflict and it is a mistake. In solving the conflict 
of Israel and Palestine, it should use humanity approach and not religion approach. Since, religion approach is really sensitive and primordial.

2. Jerussalem is a land of three divine religions: Jews, Christian and Islam. If it only uses the religion approach, then each religion work partly and incomprehensively. Mutual values among these three religions are peace and humanity. Thus, it is what should be upheld in finding the solution.

\section{Analysis on Fiqh Siyasab}

Looking at the fact of negotiation and peace agreement between Israel and Palestine since 1967 until today with all the indications, figh siyasah offers some recommendations. The word 'fiqh' etymologically means with conscious, be aware of, and acknowledge. While 'siyasah' equals to the English word of 'politics'. Wahbah Zuhaili in his book Adz-Dzara'I fi al-Siyasah asy-Syar'iyyah wal fiqh al-Islamiy defined figh siyasah as a process to comprehend context and social signs of state and state order by giving priority to the solution which is based on the guidelines of maqasid al-syariab: hifzun din (protecting religion), hifzun nafs (protecting inner being), hifzun nasal (protecting generation), hifzun maal (protecting economic independence), and hifzul ird (protecting sovereignty) (Zuhaili, 1999:9).

Based on lexical facts and political realities mentioned above, it is found some key points. They are:

1. Political Realities

a. Palestine has not yet been independent.

b. Negotiations failed.

c. Mediators took side.

d. US always vetoed for Israel.

e. The network of global economy is dominated by Israeli businessmen.

f. The impossibility to deny the existence of Israel as a part of international entity.

g. Two-state solution is the most possible solution. 
2. Lexical Realities

a. Personal pronouns (dhamir) of the word 'Yahudi (Jews)' and Israel are always plural, except in the Qur' an 3:93.

b. The word 'Israel' most of the times comes jointly with the word 'Bani' which has negative meaning. Therefore, separate the word 'bani' with the word 'Israel. The word 'bani' is a symbol of support from countries such as America or international institutions to Israel.

c. Jews and Israel are always discussed in the Qur`an as determinant factors although as minority.

d. The word 'tha 'am' which is the adjective of the word 'Israel' is a form of Freemason as funding for Israel.

From the linguistic facts and political realities above, there are some figh siyasah recommendations which are align with geopolitical realities of the conflict of Israel - Palestine. Those recommendations are explained as below:

\section{Adb-dhararu yuzal (The conflict should be stopped)}

This guideline orders that all deceptions in any form must be not only stopped but also banished. Deceptions can take a form of conflict, clash, war, disaster, crimes, robbery, terrorism, radicalism, murder, genocide, rape, etc. All five variables of maqashid shari a are attempts to prevent all those deceptions, including conflict of Israel and Palestine. Some endeavour to solve this conflict namely mediation, agreement, summit (ones of the major are Oslo Agreement and Camp David), the UN vote, OIC Summit, and the war in 6 October 1967. Even though none of them succeeded, we shall not give up and let the conflict to carry on. Adh-dhararu yuzal (the conflict must stop). This figh order should be the guidance in fiqh siyasah because siyasah or politics in Islam fight for justice, stability and welfare. The problem is how to find new just solution.

\section{Al-khuruj minal khilaf mustahab (Leaving the pros and the cons is suggested)}

This order states that in finding solution, any difference in each side must be minimised. In the case of Israel - Palestine conflict, this fiqh 
guideline works as the following: firstly, make a problem mapping. As we all know that there are four components of independence definition for Palestine (Anshari, 2009:179): (1) the withdrawal of Israel military forces from Palestine occupation territory; (2) international recognition through the UN that Palestine is a sovereign state; (3) there is no Israel as a state; (4) the restoration of Palestine land which was occupied by Israel since 1947 . In the same time, Israel demands the complete opposite. Israel insists: (1) Labelling Hamas as a terrorist movement; (2) international acknowledgment that Israel is sovereign state; (3) there is no state Palestine, there is only Palestine as a part of Israel, more likely of a province; (4) Jerussalem is owned by Israel and it becomes the capital of Great Israel (Armstrong, 2001: 705). From these contradictions, this conflict occurred; secondly, it is to compromise the differences in the Israel - Palestine conflict. By examining those four points above, it seems like a mission impossible because they negate each other. With the guideline of al-khuruj minal khilaf mustahab, figh siyasah offer two-state solution. It means either Israel or Palestine stand side by side as independent countries which should respect each other's sovereignty.

\section{Malaa yatimmul wujub illaa bibii fa buwaa waajib (anything completes the compulsory, means it is compulsory)}

In this guideline, the factors which make the conflict difficult to solve should be minimalised even eliminated. Linguistic analysis discussed previously shares information that Israel always take order from 'bani' then they together become negative. Terminology 'bani in geopolitics today has two concepts: firstly, the presence of US to support any move by Israel although it contradicts the human right; secondly, the products of Israel which become the sources for forces. It is supported with the word 'tha' 'am' in Qoran, 3:93.

US is the core element in the word 'bani. US is present all the time for Israel. It is what makes Israel arrogant because they feel US protect them. In the order of Maalaa yatimmul wujub illaa bihii fa huwaa wadjib, fiqh siyasah provides an international concept of working together to eliminate the preserving factor in the conflict of IsraelPalestine which is US for Israel. Thought-provokingly, in no disguise, 
US through President Trump announced the transfer of Israel capital from Tel Aviv to Jerussalem unilaterally which caused chaos and protest from his own citizen. It is seen that if America in its governance order and its congress become the father of Israel, another approach can be done is trough social approach. By using this approach, without seeing one's religion, this conflict of Israel and Palestine can be stopped. The preserving factor should be weakened. The international world should convince the Americans that what their government has been doing is uncivilised and harm the global peace. It is time for America to no longer be 'bani for 'Israel'.

Tha' 'am as a factor of meaning consists in the word 'bani' is the products of Israel which dominate the world and become the fuel of Israel's arrogance. Figh siyasah in this term offer international world a way to be in the same perception to boycott the product of Israel because these products implicitly the manifestation of arrogance in the word of 'bani. The order of maalaa yatimmul wujub illa bihii fa huwad waajib states that as long as the products of Israel still exist and dominate, it is difficult for the conflict to stop. In this context, peace will be pursued once Israel loses its power and arrogance. Thus, eliminating and boycott the products of Israel are compulsory.

\section{Conclusion}

The government of Indonesia has taken a positive move by coordinating with Ministers of Foreign Affairs from OIC country members. The difficult task is to work with Gulf Cooperation Council (GCC). I hope the government of Indonesia always take part in the solving of the conflict between Israel and Palestine. It is the time for Indonesia to be the example for the Middle East. We should ensure that they understand 'the tragedy of humanity' in their center of petrodollar barn. We have experience to solve the conflict in less complicated that Israel - Palestine. With all the strength and weakness, Indonesia possibly is the solving maker of the conflict. The history recorded, the liberation of Al-Aqsa Mosque had been done by other nations outside Palestine. Umar ibn Khattab and Salahuddin al-Ayyubi are two great figures who were once the negotiators and the fighters for Palestine liberation from illegal occupation. It is time for Indonesia to be the 
next Salahuddin by raising the negotiation tension and weakening diplomacy for US' veto.

From those three fiqh siyasah discussed above, adh-dhararu yuzal, al-khuruj minal khilaf mustahab, and maalaa yatimmul wujub illa bibii fa huwad wajib are the most possible to start and to socialise for Indonesia in the review of history, experience, and politics. In the historical-constitutional perspective, Palestine is one of the first countries which acknowledged the independence of Indonesia while others needed time to do so. Indonesia owe Palestine their independence. On the other hand, it is in our constitution to banish colonisation in any countries and in this case particularly Palestine. Indonesia have experience in stopping colonialization in the world. Looking at Rakhine State, Indonesia is allowed by Myanmar government because we build humanities approach and not ideological one. In this case, we are ahead of Turkey. We are building a hospital in Gaza which other people seen impossible even for Turkey since they always use ideological approach. While in this world not all of the people is Muslim. From political perspective, the most conducive and neutral is only Indonesia. Then why not the Middle East? They are drowned in their own problems and the clash between Sunni and Shi'a. Politically, Indonesia do not take side to Saudi which is Sunni nor Iran which is Shi'a. Indonesia is independent Indonesia.

\section{References}

Abdul Baqi, Muhammad Fuad, Mujjam Mufahras li Al-Faazhil Qur'anil karim, (Beirut: Dar El-Jail, 1988)

Al-Ammaari, Ali Muhammad Hasan. Min Asroril Qur'an, (Kairo: Maktabah Wahbah, 2001)

Amstrong, Karen, Holy War: The Crusades and Their Impact on Today's World (New York: Anchor Books, 2001)

Anshari, Tamim, Destiny Distrupted: A History of the World through Islamic Eyes (USA: Public Affairs, 2009)

Baqi, Muhammad Fuad Abdul. Mujjam Mufahras li Al-Faazhil Qur'anil Karim Mutaali, Abdul. Kapan Berhentinya Konflik Israel-Palestina, Media Indonesia (Kolom Opini), 27 Juli 2017.

Mutaali, Abdul. Membangun Negara Kuat: Kontribusi Islam Terbadap Pemikiran Politik Barat (Jakarta, UI Press, 2013) 


\section{Mhliam}

AHKAM Jurnal Ilmu Syariah (ISSN: 1412-4734/E-ISSN: 2407-8646) is a periodical scientific journal published by Faculty of Sharia and Law of Syarif Hidayatullah State Islamic University Jakarta in collaboration with Indonesian Scientist and Sharia Scholar Association (HISSI). This journal specifically examines the science of sharia and obtains to present various results of current and eminence scientific research. The administrators receive articles as contributions Sharia and Islamic law disciplines from scientists, scholars, professionals, and researchers to be published and disseminated. The article will be situated in a selection mechanism, a review of proved reders, and a strict editing process. All articles published in this Journal are based on the views of the authors, but they do not represent the authors' journals or affiliated institutions.

AHKAM has been accredited based on the determination of Director General of Research Reinforcement and Development, Research, and Technology Ministry of Higher Education of Republic of Indonesia, No. 36/a/E/KPT/2016 (valid until 2021). 
Mutaali, Abdul. Bangsaku di Tengah Misywar (Purwakarta, Nur El-Syam Publishing, 2009)

Mutaali, Abdul. Peta Baru Politik Timur Tengah, dalam Dari Indonesia Memandang Dunia: Sebuah Pendekatan Multidisiplin. (Jakarta: Obor, 2017)

Tim Penyusun ASPAC for Palestine, Ensiklopedia Mini Masjid Al-Aqsha, (2014)

Umar, Ahmad Muchtar. 'Ilm Al-Dilalah (Alamul Kitab: Kairo, 1993)

Zuhaili, Wahbah, Adz-Dzara'i fi al-Siyasah asy-Syar'iyyah wal Figh al-Islaamiy (Damaskus: Darul Maktabiy, 1999) 